\title{
In vitro anther culture as efficiently applied technique for doubled haploid production of wheat (Triticum aestivum L.)
}

\author{
Osama Zuhair Kanbar', ${ }^{1}$. Csaba Lantos ${ }^{2} \cdot$ Janos Pauk ${ }^{2}$
}

${ }^{1}$ Doctoral School of Plant Science, Hungarian University of Agriculture and Life Sciences, Gödöllő, Páter K u. 1, H-2103, Hungary ${ }^{2}$ Department of Biotechnology, Cereal Research Non-Profit Ltd., P.O. Box 391, H-6701 Szeged, Hungary

\begin{abstract}
Summary: In vitro anther culture is the most commonly-used technology for doubled haploid production in wheat (Triticum aestivum L.) and various cereals. The technology application allows the genetic attainment of homozygous pure lines from heterozygous breeding material in a single generation, and has become a rapid alternative to the conventional breeding methods. This technology also contributes to more accurately assess QTL $\times$ environmental interactions and has been applied in: genetic researches for marker-trait association study, genomics and as a target for transformation, genetic engineering, gene mapping, and mapping of quantitative trait loci (QTLs). This paper reviews the most important factors that limit the efficiency of winter wheat (Triticum aestivum L.) anther culture, such as genotype dependency and albinism, in addition to other affecting factors including the collection time of tillers and physiological growth environments of plants. Factors that improve the efficiency of wheat anther culture in mitigating both genotypic dependency and albinism have been included in this review, too, for example, genetic improvements by following a strategy to realize this purpose through using responsive breeding material for crossing, application of convenient stress pre-treatments (cold pre-treatments, heat shock treatment, colchicine, hormones, and chemicals) to induce androgenesis, and improvement of the composition of anther culture media and culture conditions. We have also highlighted the methods of chromosome doubling for the haploid wheat produced by anther culture androgenesis, such as spontaneous chromosome doubling or use of colchicine and anti-mitotic chemicals at an early stage of anther culture or as root immersion treatment.
\end{abstract}

Key words: anther culture, doubled haploid, Triticum aestivum L., wheat

\section{Concept and importance of the anther culture method in breeding}

Currently, most wheat breeding programs aim to attain new varieties that are characterized by high yields, excellent grain quality, good nutrient responses, and resistance to biotic and abiotic stress factors. Plant

\section{Corresponding author:}

janos.pauk@gabonakutato.hu

Acknowledgements:

The first author is thankful to Stipendium Hungaricum Scholarship program of the Hungarian government for supporting this work. This research was funded by the Hungarian Academy of Sciences, grant number "János Bolyai Research Scholarship"; National Research, Development and Innovation Office, grant number "OTKA-K_16-K119835”, "GINOP-2.2.1-15-2016-00026”, "GINOP2.2.1-18-2018-00005", "TUDFO/51757/2019-ITM" and "TKP2020-NKA-21", The authors thank Elizabeth Búza for the grammatical corrections.

Cite this article:

Kanbar O. Z., Lantos C., Pauk J. (2021). In vitro anther culture as efficiently applied technique for doubled haploid production of wheat (Triticum aestivum L.). Ratar Povrt., 58 (1), 31-45.

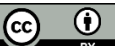

Copyright (C) The Author(s) 2021 breeders strive to realize this goal rapidly by inserting biotechnology methods with traditional breeding techniques, thereby saving costs and effort.

In vitro anther culture is one of the efficient biotechnology methods in plant breeding of wheat to produce doubled haploid lines from immature pollen grains (microspores). However, breeders can adopt it only if it ensures a sufficient rate of double haploid plants from a wide range of wheat genotypes (Barnabás et al. 2001; Trigiano \& Gray, 2016).

The success of the anther culture method is associated with the production of a high rate of embryolike structures (Fig. 1B), green plantlets (Fig. 1C), and doubled haploid lines. Low frequency of embryo-like structure formation, green plantlet regeneration, and doubled haploid production in several wheat genotypes restricts the use of anther culture in wheat breeding programs.

In nature, the original pathway of microspore development in anthers results in the formation of male gametes required for double fertilization. In in vitro anther culture, some of the microspores (Fig. 1A) 
existed in anthers can re-program their original developmental pathway under particular stress conditions by following a new sporophytic developmental pathway with continuous divisions. As a result of these divisions, haploid embryo-like structures or calli are induced, in a process known as androgenesis (Fig 1). These structures can be formed in various higher plants, including cereals (Heberle-Bors, 1985).

During sporophytic development, embryo-like structures arise after symmetrical divisions of the microspores, while the formation of calli arises after the further division of the vegetative-typed cells due to the asymmetrical division of the microspores. This was demonstrated by the results of the analysis via a transmission electron microscope (Barnabás et al., 1988).

Haploid plants containing a gametic chromosome number (n) may arise from immature pollen grains (microspores) in the process of androgenesis or an egg cell through gynogenesis, but they may arise from a gametophytic cell other than the egg cell, too, in which case, this is called apogamy. In addition, they may arise from spontaneous development or the process of hybridization.

The first report on the spontaneous development of the haploid Datura stramonium was written by Blakeslee et al. (1922). The first breakthrough in haploid breeding came in 1964 when Guha and Maheshwari performed a haploid embryo formation from an in vitro culture of Datura anthers. Shortly thereafter followed a successful in vitro haploid production of tobacco (Nitsch \& Nitsch, 1969). Since then, various successful trials have been conducted, and by 2003 more than 250 protocols covering almost all families in the plant kingdom were published, which were reviewed by Maluszynski et al. (2003).

In cereal crops, the doubled haploid technology application allows the genetic attainment of
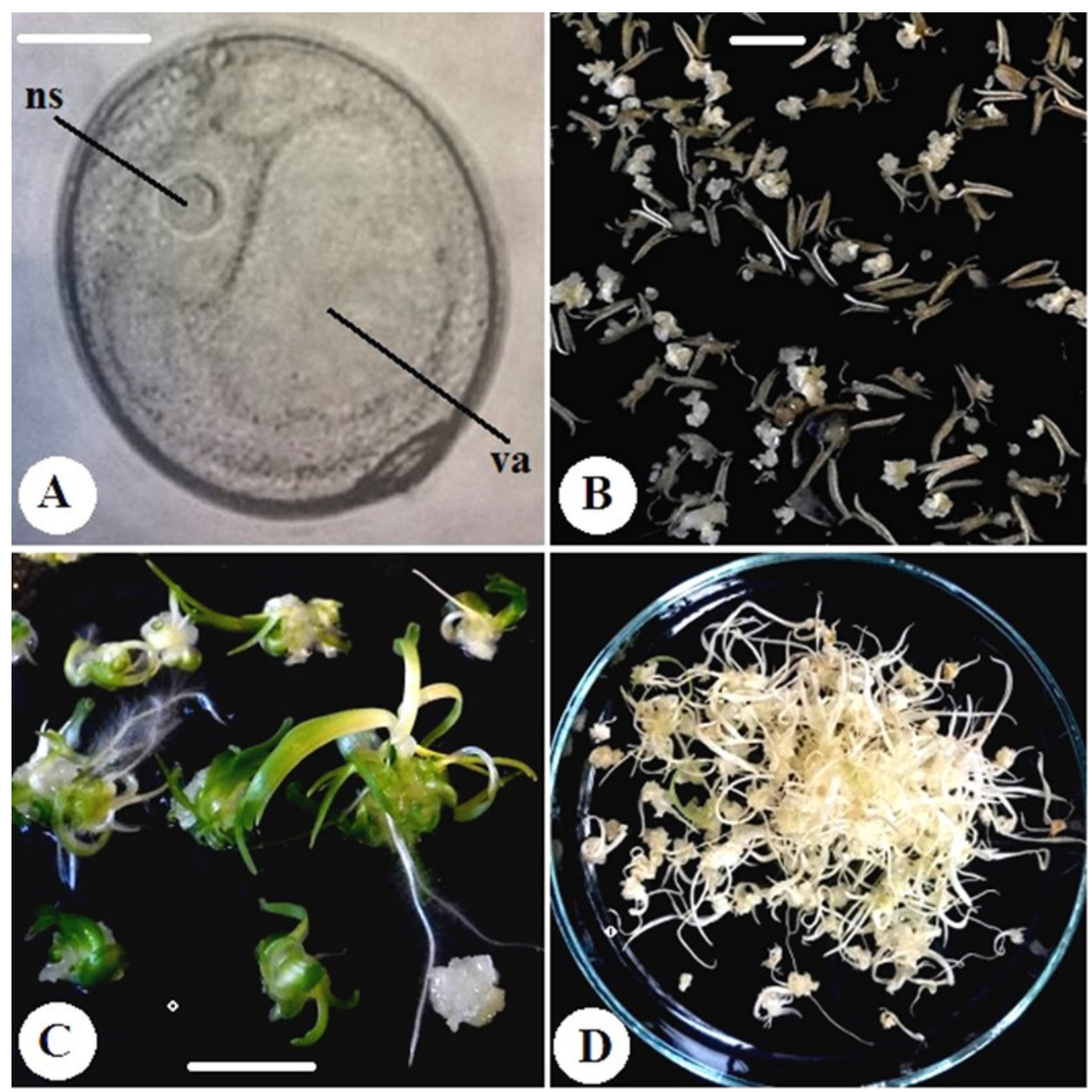

Figure 1. Androgenesis induced by in vitro anther culture in wheat: microspore at uninucleate stage (A), embryo-like structures induced after 5-8 week incubation period (B), green plantlets (C), albino plantlets (D). ns - nucleus, va - vacuole. Bar $=10 \mu \mathrm{m}$ (A), $4 \mathrm{~mm}(\mathrm{~B})$, and $1 \mathrm{~cm}(\mathrm{C})$. 
homozygous pure lines from heterozygous breeding material in a generation (Yan et al., 2017). Improvements and the adoption of this technology have rendered it a rapid alternative to the conventional breeding methods and it has become an indispensable method to realize homogeneity in various studies and programs (Wędzony et al., 2009; Lantos \& Pauk, 2016; Mahato \& Chaudhary, 2019). The technology also contributes to more accurately assess QTL $\times$ environmental interactions (Yan et al., 2017) and has been applied in: genetic researches for marker-trait association study (Sorrells et al., 2011), genomics and as a target for transformation (Murovec \& Bohanec, 2012), genetic engineering (Ravi \& Chan, 2010), gene mapping (Hao et al., 2013), and mapping of quantitative trait loci (QTLs) (Shi et al., 2019).

The chief methods applied in breeding to produce doubled haploid lines include wide hybridization, gynogenesis, and androgenesis (Dunwell, 2010). Intergeneric hybridization, e.g., crossing with maize (Zea mays L.) or Hordeum bulbosum (Suenaga et al., 1997); anther culture (Castillo et al., 2015); and isolated microspore culture are the best-known and most commonly used methods for doubled haploid production in wheat (Triticum aestivum L.) and various cereals (Lantos \& Pauk, 2016). Anther culture is an effective and applicable method that allows the production of several haploid plants from a single anther. Other cereal crops, for which protocols for doubled haploid have been applied are barley, triticale, rice, and maize (Dunwell, 2010; Niu et al., 2014). Using this approach to improve the plants, breeders have produced registered cultivars (Kush \& Virmani, 1996) and commercial varieties (Thomas et al., 2003).

In winter wheat, in vitro anther culture has been successfully utilized in different research programs for the release of new varieties, e.g., Jinghua No-1 (Hu et al., 1986), Florin (De Buyser et al., 1987), GK Délibáb (Pauk et al., 1995), McKenzi (Graf et al., 2003) and AC Andrew (Sadasivaiah et al., 2004).

Different factors that affect the androgenic production efficiency of anther culture include the genetic background of donor plants (Kondic-Spika et al., 2011); the collection timing of tillers, which reflects the developmental stage of microspores (He \& Ouyang, 1984); the physiological growth environments of the plants (El-Hennawy et al., 2011); diverse abiotic pretreatments (Islam \& Tuteja, 2012); physical factors in tissue culture, such as, light and temperature; and the composition of the anther culture medium (Broughton, 2008; Żur et al., 2015).

\section{Growing conditions and collection time of donor plants}

Donor plants have an effect on the efficiency of in vitro anther culture androgenic induction, thus also on the final doubled haploid rates. Donor plants could be grown under controlled environments (greenhouse, phytotron chamber) and non-controlled ones (field, nursery).

Controlled conditions of light and temperature allow growing of donor plants throughout the year (Torp et al., 2001; Pauk et al., 2003; Tuvesson et al., 2000, 2003; Soriano et al., 2007, 2008; Broughton, 2008, 2011; Redha \& Suleman, 2011; Castillo et al., 2015; Rubtsova et al., 2013; Coelho et al., 2018; Orlowska et al., 2020; Broughton et al., 2020). Thus, the availability of plant material for anther culture improvements and applied research are not restricted to certain months.

Under optimal growing conditions of temperature, light, and humidity, donor plants have healthy tillers and spikes that are the onset of doubled haploid production.

After germination, the winter wheat genotypes require a vernalization period of $6-8$ weeks at $3-4^{\circ} \mathrm{C}$. The ideal conditions for healthy plants are adjusted at about $18-21^{\circ} \mathrm{C} /$ day and $12-15^{\circ} \mathrm{C} /$ night with $12-18 \mathrm{~h}$ photoperiod and $70-80 \%$ humidity (Soriano et al., 2007, 2008; Sanchez-Diaz et al., 2013; Castillo et al., 2015; Coelho et al., 2018; Broughton et al., 2020). Besides, a fertilizer solution is needed to regularly nourish the donor plants.

Most of the researchers, in their studies, e.g. Pauk et al. (2003); Lantos et al. (2013); Weigt et al. (2016, 2019, 2020); Lazaridou et al. (2016); Kanbar et al. (2020a, $2020 \mathrm{~b}$ ), have used the field-grown donor plants that generate more tillers with large spikes, more anthers and microspores within anthers. This use has a positive effect on the androgenic number of embryo-like structures and green plantlets resulting in relatively high rates of doubled haploid plants for practical breeding programs and applied research.

Donor tillers should be harvested when the developmental stages of the microspores in anthers (uninucleate vacuolated microspores) are at the narrow range, viz, at early, mid, or late uninucleate stages, in order to ensure an effective anther culture technique and induce in vitro wheat anther culture androgenesis. In anther- and isolated microspore culture of wheat, the microspore embryogenic process was induced and tracked to examine the initial cell division and embryo formation of microspores (Indrianto et al., 2001; Datta, 2005; Dwivedi et al., 2015; Seldimirova et al., 2017; Niazian \& Shariatpanahi, 2020). Depending on previous publications, most researchers isolated anthers that contain microspores at mid-to-late uninucleate stages (Soriano et al., 2007, 2008; Broughton, 2008, 2011; Redha \& Suleman, 2011; Rubtsova et al., 2013; Castillo et al., 2015; Weigt et al., 2016, 2019, 2020; Lazaridou et al., 2016; Broughton et al., 2020; Orlowska et al., 2020). However, other researchers isolated anthers with microspores at early- and mid-uninucleate stage to induce androgenesis in wheat (Triticum aestivum 
L.) anther culture, e.g. Pauk et al. (1995); Tuvesson et al. (2000, 2003); Datta (2005); Lantos et al. (2013); Lantos \& Pauk (2016); Kanbar et al. (2020a, 2020b). Findings of the androgenic production of isolated anthers with microspores at the early- and mid-uninucleate stages were more effective (Pauk et al., 1995; Lantos et al., 2013; Lantos \& Pauk, 2016; Kanbar et al., 2020a, 2020b).

\section{Occurrence of albinism}

However, with androgenesis, many studies have discovered that doubled haploid production in wheat is restricted by the incidence of albinism (Islam, 2010; Broughton, 2011; Lantos et al., 2013) (Fig 1D).

Albinism regenerated by anther culture androgenesis is genetically conditioned (Zamani et al., 2000; Makowska et al., 2015), and occurs in the plantlets in case the proplastids cannot transform into chloroplasts (Makowska \& Oleszczuk, 2014).

Many complex factors may contribute to the occurrence of this incidence, such as altered transcript patterns and translation levels (Ankele et al., 2005), deletions and reorganization of the plastid genomes (Day \& Ellis, 1985) and the maternal inheritance of plastids (Vaughn et al., 1980).

Albinism appears in androgenesis-derived plants in the majority of cereals, such as wheat, barley, rye, triticale, rice, and oat. Albino plantlets in cereals can range from 5\% to $100 \%$ of regenerated plantlets. Within the same species, there was a variation between genotypes in response to albinism (Makowska \& Oleszczuk, 2014; Krzewska et al., 2015). This was demonstrated in the experiment conducted by Weigt et al. (2016) when they compared the androgenic ability of solid, medium and hollow-stemmed wheat genotypes using an in vitro anther culture method. They concluded that the solid-stemmed genotypes showed a higher frequency of albino plantlets on the medium with 2,4-D (2,4-dichlorophenoxyacetic acid) and kinetin, while the hollow-stemmed genotypes showed more albino plantlets on the medium with 2,4-D and dicamba.

Various studies were carried out to overcome the incidence of albinism in anther culture during the induction of doubled haploid plants by anther culture. The use of copper element (Jacquard et al., 2009), n-butanol treatment (Soriano et al., 2008; Broughton, 2011), co-culture of ovaries (Broughton, 2008), and polyamine treatments (Redha \& Suleman, 2011) had positive effects on the green plantlets and negative effects on the albino plantlet.

Although many researchers have reported in their research that albinism in cereal plants is an inherited trait and that nuclear genomes control this incidence (Lantos et al., 2013; Hasan et al., 2014; Krzewska et al., 2015), the interaction between genetic factors and other influencing factors such as the pre-treatment of anthers, collection time of donor plants and physical factors could also increase this incidence.

\section{Genotype dependency}

Genotype dependency is a major obstacle to doubled haploid wheat production that was developed via in vitro anther culture (Islam, 2010; Broughton, 2011; Lantos et al., 2013; Kanbar et al., 2020a, 2020b); the genotypic influence on the response to anther culture reduces the effectiveness of the anther culture method for breeding purposes (Tuvesson et al., 2000; Chen et al., 2011; Kondic-Spika et al., 2011; Dwivedi et al., 2015).

The response of wheat to androgenic induction by anther culture varies depending on genotype, species, and even within species. For instance, in hexaploid wheat, the winter genotypes have been reported to be more responsive than spring genotypes (Sharma et al., 2005). In the experiment conducted by Zamani et al. (2000), there were somewhat different results. They also found namely, that the embryo-like structures induced by anther culture were more efficient in the winter wheat genotypes than in the spring genotypes, but the regeneration of green plantlets from spring genotypes was much higher than from winter genotypes. Chaudhary et al. (2003) studied the androgenetic production of nine elite winter wheat genotypes and two spring wheat ones via anther culture method. Their results showed that the spring genotypes achieved a higher number of embryo-like structures and green plantlets. Grauda et al. (2014) investigated the androgenetic induction of sixteen winter wheat hybrids and five spring hybrids by anther culture method. They asserted that the spring wheat hybrids produced higher embryogenesis than the winter wheat hybrids, but the winter wheat hybrids had higher green plantlet regeneration than the spring wheat hybrids. Holme et al. (1999) revealed in their studies, that the wheat genotypes of Northwestern Europe responded less than their Eastern European counterparts. Lazaridou et al. (2016) compared the embryo-like structures and the regeneration of the green plantlets of bread wheat AABBDD with their extracted tetraploid $A A B B$ via anther culture when they applied three different pretreatments: a cold pre-treatment for 7 and 18 days at $4^{\circ}$ $\mathrm{C}$, and $0.3 \mathrm{M}$ mannitol for 7 days at $4^{\circ} \mathrm{C}$. Their results revealed that the androgenic response was better in the winter wheat genotypes than in the extracted tetraploid. Besides, no green plantlets were obtained from tetraploid wheat for any pre-treatment, and the results confirmed the role of the $\mathrm{D}$ genome in the androgenic response of anther culture in wheat. Accordingly, the hexaploid wheat (Triticum aestivum L.) is characterized as well-responding in anther culture and has been widely 
and successfully used (Kasha \& Maluszynski, 2003), while the efficiency of anther culture in durum wheat (Triticum turgidum L.) was weak and almost no green plantlets were regenerated due to the lack of $\mathrm{D}$ genome (Cistué et al., 2009; Lazaridou et al., 2016). Possible interactions between the three genomes, A, B and D of the hexaploid wheat (Triticum aestivum L.) may stimulate the androgenic response in anther culture.

\section{Increasing the efficiency of wheat anther culture}

The in vitro anther culture system has been effective only for a restricted number of responsive genotypes, and other genotypes still do not respond to it. Therefore, methods that are more efficient in stimulating androgenesis in a wide range of wheat genotypes are needed.

Genotype dependency and albinism are the most limiting factors for doubled haploid production based on androgenesis through anther culture (Islam, 2010; Broughton, 2011; Lantos et al., 2013). Thereby, the factors that improve the efficiency of wheat anther culture in mitigation for genotypic dependency and the incidence of albinism should be identified.

\subsection{Genetic improvement}

Studies have been conducted in the recent decades to enhance the efficiency of wheat anther culture through genetic improvement; Tuvesson et al. (2000), for example, elaborated a strategy to realize this purpose through using responsive breeding material for crossing. The success of this strategy depends on the precondition, that one parental plant materials in each crossing should previously produce at least one green plantlet/spike in anther culture (Tuvesson et al., 2003). The use of responsive plant material has also been proposed in other breeding programs depending on the anther culture (González et al., 2006; Kondic-Spika et al., 2011).

Marciniak et al. (2003), Dagüstü (2008), Yildirim et al. (2008), and Al-Ashkar (2014) have reported that the embryo-like structure formation and regeneration of green plantlets are inherited traits in anther culture. Chaudhary et al. (2003), Dagüstü (2008) and Grauda et al. (2016) have found that an additive, dominant, and epistatic gene influences the control over the inheritance pattern of the androgenic traits in anther culture; while some findings have indicated that the androgenic response in anther culture follows a simple inheritance pattern and is controlled by dominant genes (ElHennawy et al., 2011), which can easily be transferred from highly responsive genotypes to low responsive ones through crossing process with the expected rapid genetic gain.

\subsection{Application of stress pre-treatments in anther culture}

In in vitro anther culture method, most studies to improve this method focus on the application of convenient stress pre-treatments, like cold pretreatments, heat shock treatment, colchicine, hormones, and chemicals to induce androgenesis in cereals (Labbani et al., 2007), where this stress results in the repeated equivalent divisions of the microspore nucleus, thus the microspore development converts from the gametophytic pathway to sporophytic one (Zhou \& Konzak, 1997; Zheng \& Konzak, 1999; Barnabás et al., 1991; Lazaridou et al., 2016; Broughton et al., 2020; Weigt et al., 2020). The application of the pre-treatment should be convenient in order not to lead to a high mortality rate of cells or impair the cellular function (Makowska \& Oleszczuk, 2014).

Cold pre-treatment of donor tillers is the favourite way to reprogram the microspores. In vitro androgenesis of microspores can be induced through long cold pretreatment of donor tillers at $2-5^{\circ} \mathrm{C}$, for $10-28$ days) (Pauk et al., 2003; Lantos et al., 2013; Lantos \& Pauk, 2016; Coelho et al., 2018; Kanbar et al., 2020a, 2020b). Short cold pre-treatment at $4-6^{\circ} \mathrm{C}$ for $3-8$ days can also be efficient for induction of androgenesis (Broughton 2008, 2011; Rubtsova et al., 2013; Weigt et al. 2016, 2019; Lazaridou et al., 2016).

Lazaridou et al. (2016) conducted a study using the wheat anther culture method to study the role of the D genome in the androgenic response and to investigate the interaction between the genotype and the pretreatments, which included 7 days of pre-treatment at $4^{\circ} \mathrm{C}, 18$ days of pre-treatment at $4^{\circ} \mathrm{C}$, and $0.3 \mathrm{M}$ mannitol for 7 days at $4^{\circ} \mathrm{C}$. They concluded that the tetraploid wheat (Triticum turgidum L.) attained lower induction of embryo-like structures and no regeneration of green plantlets in the three pre-treatments compared to the hexaploid wheat (Triticum aestivum L.), and the genotypes responded better after 7 days of cold pretreatment of spikes. However, within hexaploid wheat, the genotypes differed in their androgenic responses to the three treatments, with the Canadian genotypes responding better at $4^{\circ} \mathrm{C}$ after 18 days of cold-pretreatment than the controls, which responded better after 7 days of cold pre-treatment. In addition, the mannitol had a negative influence on the embryo-like structures of some hexaploid genotypes as well as on the production of green plantlets in all hexaploid genotypes. In the study by Lazaridou et al. (2016), the results showed that there was a high interaction between the genotype and the cold pre-treatments of winter wheat spikes and this contradicted to Rizkalla et al. (2012) who emphasized that winter wheat genotypes achieved almost the same embryo-like structure induction after cold pre-treatments of spikes for 7 or 14 
days. In most trials, cold pre-treatment was efficiently applied to different cereal crops for this purpose; TrejoTapia et al. (2002) discovered that the cold pretreatment in rice played a decisive role for the induction of embryo-like structures by anthers of the parental lines and $\mathrm{F}_{1}$ hybrids.

Various protocols on the effect of the presence of mannitol during the cold pre-treatment stage in the androgenic induction of wheat have been proposed. In the efforts of Cistué et al. (2006) to improve the androgenic response of durum wheat (Triticum turgidum L.), the results revealed that the 5-day pre-treatment of the anthers with $0.7 \mathrm{M}$ mannitol had a positive effect on the green plantlet number. Soriano et al. (2007) and Castillo et al. (2015) found that the 5-day pre-treatment of winter wheat (Triticum aestivum L.) anthers with 127.5 $\mathrm{g} / \mathrm{L}$ mannitol led to satisfactory results of the androgenic induction. Furthermore, Labbani et al. (2007) asserted that the interaction between the combination of cold and $0.3 \mathrm{M}$ mannitol pre-treatments of anthers over 7 days was effective on the embryo-like structure formation and the green plantlet regeneration of the tetraploid wheat (Triticum turgidum L.). None of the results of Labbani et al. (2007), however, was confirmed in the findings by Lazaridou et al. (2016) due to the negative influence of mannitol on androgenic induction of durum and winter wheat.

Heat shock treatment of isolated anthers at $32^{\circ} \mathrm{C}$ for $36 \mathrm{~h}$ in the dark was commonly applied in anther culture method as a stress factor to improve androgenesis in winter wheat (Ouyang et al., 1983; Pauk et al., 2003; Lantos et al., 2013; Lantos \& Pauk, 2016; Kanbar et al., 2020a, 2020b). According to a report by Ouyang et al. (1983), the ideal incubation temperature of isolated anthers after heat treatment in cereal crops was between $28-30^{\circ} \mathrm{C}$. Higher incubation temperatures may lead to an increased occurrence of albino plantlets.

In microspore embryogenesis, Seldmirova et al. (2016) and Biesaga-Kościelniak (2001) demonstrated that auxin gradients play an essential role in setting up embryo symmetry and that the exact ratio of endogenous and exogenous auxins in the microspores controls the development pathway of the microspores towards embryo-like structure formation. The type and length of exposure to the stress factor mainly influence the accumulation of endogenic auxins. Based on this report, it is crucial to choose the convenient primary treatment and appropriate concentration of hormones applied to the induction medium in such a way that the total concentration of all auxins within a cell can be optimized. The type and concentration of the auxins and the type of carbon source affected the induction of embryo-like structures (Trejo-Tapia et al., 2002).

The auxin herbicide 2,4-D is widely used as growth hormone to induce embryo-like structures (Przetakiewicz et al., 2003; Seldimirova et al., 2016). Previous studies showed that this synthetic hormone added to the induction medium behaved as a stress factor and had auxin-like effects (Fehér, 2005). Its favourable concentration in the induction medium was between 0.5 and $2.0 \mathrm{mg} / \mathrm{L}$ for this purpose (Weigt et al., 2019). Excessive concentrations, over $2.0 \mathrm{mg} / \mathrm{L}$, caused loss of the embryo-like structures' ability to regenerate into plantlets because the stress hormones accumulated and hindered the further development of embryos (Zheng \& Konzak, 1999). Too low concentrations of auxin, below $0.5 \mathrm{mg} / \mathrm{L}$, did not stimulate embryo-like structures induction at all (Gorbunova et al., 2001).

In studies on wheat microspore embryogenesis, various growth hormones are included as stress factors in induction media, such as dicamba, kinetin, picloram (Chaudhary et al., 2003; Cistué et al., 2006), PAA (Ziauddin et al., 1992; Kim \& Baenziger, 2005), and BAP (Cistué et al., 2006; Ponitka \& ŚlusarkiewiczJarzina, 2009). Zearalenone was also used in the induction medium as a stress factor for embryo-like structure induction; it had auxin-like effects (Szechyńska-Hebda et al., 2007; Weigt et al., 2019). Weigt et al. (2019) used anther culture method to test the influence of zearalenone and hormone regulators on microspore embryogenesis in $13 \mathrm{~F}_{1}$ hybrids of winter wheat and six $F_{1}$ hybrids of spring genotypes. They studied two combinations of growth hormones: the auxins (2,4-D + dicamba), and auxin and cytokinin (2,4-D + kinetin), each with three zearalenone concentrations of $0 \mathrm{~mL} / \mathrm{L}, 0.1 \mathrm{~mL} / \mathrm{L}, 0.2 \mathrm{~mL} / \mathrm{L}$, thus forming six combinations of media. The results revealed that the media containing zearalenone caused an efficient increase in the number of embryo-like structures and green plantlets in some hybrids. Moreover, the increased concentration of zearalenone effectively improved the embryo-like structure induction. The induction medium of $2,4-\mathrm{D}+$ dicamba supplemented with $0.2 \mathrm{~mL} / \mathrm{L}$ zearalenone was the most effective. By using zearalenone together with growth hormones, all hybrids produced embryo-like structures, where the non-responsive wheat hybrids were stimulated, besides green plantlet regeneration was found in 18 of the 19 studied hybrids. Adding zearalenone to the induction medium did not have effect on the number of albino plantlets or the frequency of spontaneous doubled haploid plants.

Colchicine affects the androgenic response in wheat, and various researchers have discovered that colchicine has a positive effect on embryo-like structure induction or/and green plantlet regeneration, and this effect varied depending on genotype (Barnabás et al., 1991; Hansen \& Andersen, 1998a; Soriano et al., 2007). The presence of colchicine in the induction medium caused a significant increase of embryo-like structures in wheat (Barnabás et al., 1991; Barnabás \& Kovács, 1992). In order to increase the haploid frequency in anther culture, it could be more efficient to apply low concentrations of $0.01,0.02$, and $0.04 \%$ of this 
chromosome-doubling agent (colchicine) supplied to the induction medium (Barnabás et al., 1991).

There was a confirmation that the herbicides: trifluralin, oryzalin and APM (aminoprophos-methyl) had the same effect as colchicine in stimulating androgenesis. The study carried out by Hansen \& Andersen (1998b) found that trifluralin and APM affected the induction of embryo-like structures in wheat microspores. Hansen \& Andersen (1996) reported that oryzalin, trifluralin and APM also had effect on the embryo-like structure induction in Brassica napus. In their investigation, the tested concentrations of herbicides were $0.1-10 \mu \mathrm{M}$ with wheat and $0.3-30 \mu \mathrm{M}$ with Brassica napus for 24 and $48 \mathrm{~h}$ exposure times. The appropriate herbicide concentrations for embryo-like structure induction and green plantlet regeneration ranged from $0.3-1.0 \mu \mathrm{M}$, but the higher herbicide concentrations impeded the embryo-like structure formation and regeneration of green plantlets in both species. In contrast, the increased concentrations of these herbicides steadily enhanced the rate of plant fertility, and hence the doubled haploid plant production. Broughton et al. (2020) investigated the effects of trifluralin on the androgenic induction of wheat by anther culture method and selected 1 and 3 $\mu \mathrm{M}$ trifluralin concentrations and exposure times (24, 48 h) based on the study of Hansen \& Andersen (1998b). The results indicated that the application of trifluralin did not achieve positive effect on the number of embryo-like structures and green plantlets even when a low concentration of $1 \mu \mathrm{M}$ trifluralin was applied. These observations assert that trifluralin may only be used in wheat microspore method.

Due to existence of the strong genotype dependency between spring and winter wheat, it is indispensable to select the proper pre-treatment factors, such as cold pre -treatment, concentration, and hormone type in the induction medium adjusted either to the spring or the winter wheat. This was one of the indispensable solutions to increase the androgenic efficiency (Weigt et al., 2020). Winter wheat (Triticum aestivum L.) is more tolerant to low temperatures. This fact leads to differences in the level of endogenous hormones induced in cells of spring and winter wheat during cold stress, and thus affects the efficiency of androgenesis. Weigt et al. (2020) tested fifteen winter- and fifteen spring wheat genotypes separately using the microspore androgenesis method and analysed the differences between them in response to hormone content. They utilized C17 induction medium, which was supplemented with two combinations of growth hormones: I- the auxins only (1 $\mathrm{mg} / \mathrm{L}$ of 2,4dichlorophenoxyacetic acid (2,4-D) + $1 \mathrm{mg} / \mathrm{L}$ of dicamba, and II- auxin and cytokinin $(1.5 \mathrm{mg} / \mathrm{L}$ of 2,4 $-\mathrm{D}+0.5 \mathrm{mg} / \mathrm{L}$ of kinetin). The results revealed that the spring genotypes responded better to embryo-like structures and green plantlets in C17 with hormone I and C17 with hormone II compared to the winter genotypes. Furthermore, within the spring wheat genotypes, a higher androgenic rate of embryo-like structures and green plantlets was achieved in $\mathrm{C} 17$ with hormone I compared to $\mathrm{C} 17$ with hormone II; in contrast, the winter wheat obtained more androgenic production of the embryo-like structures and green plantlets in C17 with hormone II compared to C17 with hormone I. Thus, selecting proper composition of the medium is essential for increasing the efficiency of anther culture application.

Caffeine or trifluralin was applied at the beginning of the induction phase to enhance the early chromosome doubling and androgenic induction (Broughton et al., 2020). Caffeine can stimulate the formation of embryo-like structures and the regeneration of green plantlets and influences the phragmoplast microtubules during cell division and cytokinesis (Yasuhara, 2005). This was reported in the study by Broughton et al. (2020) when modest improvements were achieved in the regeneration of green plantlets in two crosses of six spring wheat using $0.5 \mathrm{mM}$ caffeine treatment for $24 \mathrm{~h}$ at the beginning of the induction phase. The increase of green plantlets was $14 \%$ in one cross and $27 \%$ in the other. In addition, the cytoskeleton re-programmed the microspores towards androgenesis (Touraev et al., 2001; Seguí-Simarro \& Nuez, 2008).

Colchicine and different herbicides disturb spindle microtubules and prompt the microspore embryogenesis in various species, while $n$-butanol has influence on cortical microtubules and prompts the androgenesis in wheat (Soriano et al., 2008; Broughton, 2011).

Ding et al. (1991) demonstrated that a low dose of gamma ray (up to $7 \mathrm{~Gy}$ ) could also improve the anther culture response in wheat.

\subsection{Composition of anther culture media and culture conditions}

In recent decades, many studies have been conducted to improve the efficiency of the anther culture induction medium. P4 (Pauk et al., 2003), P2 (Kondic-Spika et al., 2011), and W14 (Rubtsova et al., 2013; Lantos \& Pauk, 2016; Lazaridou et al., 2016) are the most commonly used induction media for the anther culture androgenesis of winter wheat (Triticum aestivum L.). There are also other induction media such as MS3M (Soriano et al., 2007; Sanchez-Diaz et al., 2013; Castillo et al., 2015) C17 (Weigt et al., 2020) (Table 1), LIM (Broughton et al., 2020), and AM. These media contain maltose as a carbon source (Hunter, 1987) and Ficoll as an osmotic agent (Datta \& Wenzel, 1987). Recently, W14 and MS3M media have been widely used in haploid experiments and wheat breeding programs. W14 medium has been modified to W14mf 
synthetic medium (Table 1), which has been effectively used in wheat research and breeding programs (Lantos et al., 2013, Lantos \& Pauk, 2016; Kanbar et al., 2020a, 2020b). Some organic components such as potato extract and wheat ovaries were reported to enhance the efficiency of in vitro anther culture (Datta \& Wenzel, 1987; Brougton, 2008, 2011; Castillo et al., 2015; Broughton et al., 2020).

Table 1. Composition of some of the different media used in wheat anther culture

\begin{tabular}{|c|c|c|c|c|c|c|}
\hline \multirow{2}{*}{ Media components } & \multicolumn{3}{|c|}{ Induction medium (mg/L) } & \multicolumn{3}{|c|}{ Regeneration medium (mg/L) } \\
\hline & $\mathrm{C} 17$ & W14 & W14mf & MS & $190-2$ & $190-2 \mathrm{CU}$ \\
\hline \multicolumn{7}{|l|}{ Macro salts } \\
\hline $\mathrm{KNO}_{3}$ & 1,400 & 2,000 & 2,000 & 1,900 & 1,000 & 1,000 \\
\hline $\mathrm{KCl}$ & & - & - & - & 40 & 40 \\
\hline $\mathrm{K}_{2} \mathrm{SO}_{4}$ & & 700 & 700 & - & - & - \\
\hline$\left(\mathrm{NH}_{4}\right)_{2} \mathrm{SO} 4$ & & - & - & - & 200 & 200 \\
\hline $\mathrm{NH}_{4} \mathrm{NO}_{3}$ & 300 & - & - & 1,650 & - & - \\
\hline $\mathrm{KH}_{2} \mathrm{PO}_{4}$ & 400 & - & - & 170 & 300 & 300 \\
\hline $\mathrm{NH}_{4} \mathrm{H}_{2} \mathrm{PO}_{4}$ & & 380 & 380 & - & - & - \\
\hline $\mathrm{CaCl}_{2} \cdot 2 \mathrm{H}_{2} \mathrm{O}$ & 150 & 140 & 140 & 332.2 & - & - \\
\hline $\mathrm{Ca}(\mathrm{NO} 3) 2 \cdot 4 \mathrm{H} 2 \mathrm{O}$ & & - & - & - & 100 & 100 \\
\hline $\mathrm{MgSO}_{4} \cdot 7 \mathrm{H}_{2} \mathrm{O}$ & 150 & 200 & 200 & 180.7 & 200 & 200 \\
\hline \multicolumn{7}{|l|}{ Iron source } \\
\hline $\mathrm{Na}_{2}$ EDTA & 37.8 & 37.3 & 37.3 & 37.2 & 37.3 & 37.3 \\
\hline $\mathrm{FeSO}_{4} \cdot 7 \mathrm{H}_{2} \mathrm{O}$ & 27.8 & 27.8 & 27.8 & 27.8 & 27.8 & 27.8 \\
\hline \multicolumn{7}{|l|}{ Micro salts } \\
\hline $\mathrm{MnSO}_{4} \cdot 4 \mathrm{H}_{2} \mathrm{O}$ & 11.2 & 8 & 8 & 16.9 & 8 & 8 \\
\hline $\mathrm{ZnSO}_{4} \cdot 7 \mathrm{H}_{2} \mathrm{O}$ & 8.6 & 3 & 3 & 8.6 & 3 & 3 \\
\hline $\mathrm{H}_{3} \mathrm{BO}_{3}$ & 6.2 & 3 & 3 & 6.2 & 3 & 3 \\
\hline $\mathrm{KI}$ & 0.86 & 0.5 & 0.5 & 0.8 & 0.5 & 0.5 \\
\hline $\mathrm{CuSO}_{4} \cdot 5 \mathrm{H}_{2} \mathrm{O}$ & 0.025 & 0.025 & 0.025 & 0.025 & - & 0.5 \\
\hline $\mathrm{CoCl}_{2} \cdot 6 \mathrm{H}_{2} \mathrm{O}$ & 0.025 & 0.025 & 0.025 & 0.025 & - & - \\
\hline $\mathrm{Na}_{2} \mathrm{MoO}_{4} \cdot 2 \mathrm{H}_{2} \mathrm{O}$ & & 0.005 & 0.005 & 0.25 & - & - \\
\hline \multicolumn{7}{|l|}{ Vitamins } \\
\hline Myo-Inositol & 100 & 500 & - & 100 & 100 & 100 \\
\hline Thiamine $\mathrm{HCl}$ & 1 & 2 & 2 & 0.1 & 1 & 1 \\
\hline Pyridoxine $\mathrm{HCl}$ & 0.5 & 0.5 & 0.05 & 0.5 & 0.5 & 0.5 \\
\hline Folic acid & 0.5 & - & - & & - & - \\
\hline Nicotinic acid & 0.5 & 0.5 & 0.05 & 0.5 & 0.5 & 0.5 \\
\hline \multicolumn{7}{|l|}{ Other components } \\
\hline Glycine & 2 & 2 & - & 2 & 2 & 2 \\
\hline L-cysteine & - & 50 & - & - & - & - \\
\hline Biotine & 1 & - & - & - & - & - \\
\hline Sucrose & - & - & - & 30,000 & 30,000 & 30,000 \\
\hline Maltose & 90,000 & 90,000 & 90,000 & - & - & - \\
\hline $2,4-\mathrm{D}$ & 1.5 & 5 & 2 & 2.5 & - & - \\
\hline Kinetin & 0.5 & - & 0.5 & - & 0.5 & 0.5 \\
\hline PFA & 20 & - & - & - & - & - \\
\hline BAP & - & 0.5 & - & - & - & - \\
\hline Etephon & - & 20 & - & - & - & - \\
\hline NAA & - & - & - & - & 0.5 & 0.5 \\
\hline Ficoll 400 & - & 100,000 & 100,000 & - & - & - \\
\hline Agar & - & - & - & 8,000 & 6,000 & - \\
\hline Agarose & 6,000 & 6,000 & - & - & - & - \\
\hline Gelrite & & - & - & - & 3,000 & 3,000 \\
\hline $\mathrm{PH}$ & 5.8 & 5.8 & 5.8 & 5.8 & 6 & 5.8 \\
\hline
\end{tabular}


The most commonly used regeneration media in anther culture are 190-2 (Tuvesson et al., 2000; Lazaridou et al., 2016; Orlowska et al., 2020), J25-8 (Soriano et al., 2007, 2008; Castillo et al., 2015) and MS (Rubtsova et al., 2013; Weigt et al., 2016, 2019) (Table 1). 190-2 regeneration medium was modified to 190 2Cu (Table 1) and proved to be efficient regeneration medium in wheat research and breeding programs, too (Pauk et al., 2003; Lantos et al., 2013; Lantos \& Pauk, 2016; Kanbar et al., 2020a, 2020b). The embryo-like structures are incubated in a growth chamber for a period of approximately two weeks at $22-26^{\circ} \mathrm{C}$ with 16 $\mathrm{h}$ photoperiod to regenerate green and albino plantlets in a diverse proportion.

\section{Production of green plantlets via in vitro anther culture}

Although many studies have made progress in improving in vitro anther culture by following a specific protocol (Broughton et al., 2008, 2011, 2020; Soriano et al., 2008; Lantos et al., 2013), there is still a variation between wheat genotypes in response to anther culture method. Some studies reported a maximum production of green plantlet over 100 green plantlets/100 anthers (Broughton, 2011, 2020; Lantos et al., 2013; Castillo et al., 2015). The maximum values less than 25 green plantlets/100 anthers were reported in the studies of Kim \& Baenziger (2005); Khiabani et al. (2008); Kondic -Spika et al. (2008); El-Hennawy et al. (2011); Grauda et al. (2014); Weigt et al. (2019); Orlowska et al. (2020); Kanbar et al. (2020a, 2020b). Some findings recorded maximum values between 25-37 green plantlets/100 anthers (Trottier et al., 1993; Navarro-Alvarez et al., 1994; Lantos et al., 2013; Weigt et al., 2020). The total average of the production of green plantlets/100 anthers, which is between 0.40 and 9.76 green plantlets/100 anthers depending on the used protocol was recorded from previous winter wheat breeding programs by Masojc et al. (1993); Holme et al. (1999); Tuvesson et al. (2000); Kondic-Spika et al. (2008); ElHennawy et al. (2011); Grauda et al. (2014); Weigt et al. (2019, 2020); Kanbar et al. (2020a, 2020b).

\section{In vivo acclimatization of plantlets}

After acclimatization, the frequency of transplanted plantlet losses resulted from the hardening of the plantlets - transferring them gradually from high to low humidity and from low light intensity to high light intensity, in addition to transplantation to suitable substrates of sand, peat, compost etc. These losses can be overcome by applying a suitable concentration of sucrose $(2-4 \%)$ or growth retardants to plantlet shooting and rooting medium, and also reducing the moisture in the culture boxes by adding oily substances that subsequently improve the growth of the plants in in vivo. Although experiments to optimize the circumstances for micropropagation of plantlets in in vivo were not fully present, studies carried out on the improvement of the conditions for in vitro plantlet micropropagation of various plants and subsequently improved the acclimatization of plantlets in the greenhouse (Pospisilova et al., 1999; Hazarika, 2003). Besides, the transfer of plantlets from the laboratory to greenhouse or field (nursery) is a critical point of this work and experiments. The increase in the frequency of in vivo plantlet is largely dependent on the improvements of in vitro plantlet shooting and rooting medium, the genetic effect, the human background, and the technical equipment. Among the regenerated plantlets, there is a low rate $(5-10 \%$, depending on the season) of the chimeric and genetically changed individuals (monosome, trisome, etc.), which need special care. These individuals are not advantageous for breeding programs. As a rule, they degenerate and do not survive the greenhouse- or field (nursery) breeding circumstances.

\section{Chromosome doubling}

The haploid plants that are regenerated from diploid species have only one set of chromosomes and are characterized by being smaller, weak, and infertile because chromosomes cannot be doubled during meiosis. They could spontaneously restore their fertility or use stimulants so that they can be used in breeding programs. Chromosome doubling occurs when a factor is applied that prevents spindle formation during mitosis and thus impedes the normal segregation of sister chromatids towards the poles. Doubled haploid plants are homozygous at all loci representing a new variety.

Spontaneous double haploid is normally present in cereal plants produced by anther culture, and it is a safe method because chemical treatments, such as colchicine, are toxic to humans. Prior to genetic characterization of new lines for quantitative traits, spontaneous doubled haploid plants produce more grains compared to plants treated with chemical compounds (colchicine) (Chaudhary et al., 2015). Spontaneous chromosome doubling, which restores the fertility in cereals, offers the chance to avoid the examination of regenerated plants for ploidy determination, the treatment of haploid plants with colchicine by root immersion (Jensen, 1974; Inagaki, 2003), and also to avoid the problems of plants associated with mortality, ploidy chimaeras and variable seed set caused by this treatment (Soriano et al., 2007). Nuclear fusion is widely known as a mechanism for spontaneous chromosome doubling in microsporederived haploid wheat and barley (Kasha, 2005; 
Daghma et al., 2014). However, the spontaneous doubling rate for winter wheat (Triticum aestivum L.) in the report of Castillo et al. (2009) ranged between 25\% and $70 \%$. Lantos \& Pauk (2016) recorded a value of $17.65 \%$ to $60 \%$. Weigt et al. (2019) achieved a spontaneous doubled haploid plant rate varying between $27 \%$ and $43 \%$ depending on the genotype. Broughton et al. (2020), who treated Australian spring wheat crosses with caffeine or trifluralin, obtained a spontaneous rate between $14 \%$ and $80 \%$. Kanbar et al. (2020b) achieved spontaneous doubling rates for winter wheat (Triticum aestivum L.) between $25 \%$ and $87.76 \%$. Total rates of spontaneous doubled haploid were $49 \%, 47.90 \%, 35 \%$, $32.72 \%$, and $59.74 \%$ in the studies of Kim \& Baenziger (2005), Kondic-Spika et al. (2008), Lantos et al. (2013), Lantos \& Pauk (2016), Kanbar et al. (2020b), respectively. Spontaneous doubled haploid winter wheat (Triticum aestivum L.), varying between 5\% and 30\%, were presented in early studies conducted by Ziegler et al. (1990); Masojc et al. (1993); and Navarro-Alvarez et al. (1994).

Colchicine, an anti-mitotic chemical, was successfully added at an early stage of anther culture and microspore media to improve genome doubling in wheat (Soriano et al., 2007; Barnabás et al., 1991; Hansen \& Andersen, 1998a). Colchicine should be utilized in relatively high concentrations to achieve an affinity to plant microtubules and thus the chromosome doubling (Morejohn et al., 1984; Morejohn et al., 1987a), but the negative aspect of this use is that colchicine has a toxic effect on humans and a high affinity to vertebrate microtubules (Dhooghe et al., 2011). The 0.1\% (w/v) (2.5 $\mathrm{mM}$ ) concentration of colchicine is frequently applied for root dipping treatment in cereals (Jensen, 1974; Inagaki, 2003), however, lower concentrations between 0.3 and $1.0 \mathrm{mM}$ are used in in vitro anther and microspore cultures (Soriano et al., 2007; Hansen \& Andersen, 1998a). In the study by Soriano et al. (2007), they observed that the Pavon wheat variety achieved fewer improvements in a chromosomal doubling when using colchicine in anther culture compared with microspore culture. It is worth mentioning that the $0.1 \%(\mathrm{w} / \mathrm{v})(2.5 \mathrm{mM})$ concentration of colchicine is mostly used for root dipping treatment in cereals (Jensen, 1974; Inagaki, 2003).

Many herbicides target mitosis and have a mechanism for doubling chromosomes, such as dinitroanilines (trifluralin and oryzalin), benzamides (pronamide), phosphorothioamidates (aminoprophosmethyl or APM), as well as carbamates (chlorpropham and isopropyl N-3-chlorophenyl carbamate) (Dhooghe et al., 2011). Studies clarified the mechanism of oryzalin and APM, which included binding to tubulin proteins, inhibiting the polymerization of microtubules and stimulating the depolymerization of the anaphase spindle (Morejohn et al., 1987b; Murthy et al., 1994).
Mitosis and cell division are prohibited, and affected cells may involve polyploid nuclei. These chemicals have led to diploidization in many plant species (Dhooghe et al., 2011). In addition to colchicine, trifluralin, oryzalin, and APM have also been used to double chromosome during androgenesis in wheat (Hansen \& Andersen, 1998b). Since these chemicals have a much higher affinity to plant microtubules than colchicine, they can therefore be used in the micromolar concentrations (Morejohn et al., 1987b; Bajer \& MolèBajer, 1986). Additionally, these chemicals do not bind to animal microtubules (Morejohn et al., 1987b; Murthy et al., 1994; Bajer \& Molè-Bajer, 1986) thereby reducing the risk of toxicity to humans. In previous studies, relatively higher concentrations of oryzalin, trifluralin and APM had similar in vitro effects like colchicine in improving chromosome doubling in wheat. The highest frequency of fertile plants was attained by the concentration of $10 \mu \mathrm{M}$ trifluralin or APM used for $48 \mathrm{~h}$.

In anther culture, androgenesis and early genome doubling can be attained when chemical herbicides, such as caffeine or trifluralin are used at an early stage in the induction medium required for embryo-like structure prompt, then doubled haploid and fertile plants are spontaneously produced (Broughton et al., 2020). The investigation carried out by Broughton et al. (2020) showed that trifluralin significantly improved the chromosome doubling in the control genotype of wheat (Triticum aestivum L.) after pre-treatment of $1 \mu \mathrm{M}$ and 3 $\mu \mathrm{M}$ for $48 \mathrm{~h}$, from $38 \%$ to $51 \%$ and $53 \%$, respectively. Trifluralin, however, led to a negative effect on the regeneration of green plantlet/20 anthers in the same genotype and minimized the number from 31.8 to 9 and 25 , respectively. The use of caffeine in this experiment did not record significant improvements in the doubling of chromosome in the wheat anther culture, while it was not tested for in vitro microspore culture as an agent for the chromosome doubling purpose. Caffeine was tested in haploid interspecific (wheat $\times$ maize) crosses instead of colchicine to double the genome in wheat (Thomas et al., 1997), where root dipping treatments with the tested concentrations of 0.3 $-10 \mathrm{~g} / \mathrm{L}$ and a duration of 3-24 h were used. Caffeine can be used as an agent for restoring fertility in wheat via root dipping treatment and the best result of the discovered fertility was achieved with $3 \mathrm{~g} / \mathrm{L}(15.4 \mathrm{mM})$ applied for $24 \mathrm{~h}$, when various concentrations were tested (Thomas et al., 1997).

Sugar starvation was widely-applied as stress pretreatment involving placing the anthers on a medium containing mannitol as a carbohydrate source (Caredda et al., 2000; Kasha et al., 2001; Cistué et al., 2006; Soriano et al., 2007; Castillo et al., 2015). This pretreatment resulted in a high rate of chromosome doubling in barley (Kasha et al., 2001; Shim et al., 2006), and wheat (Hu \& Kasha, 1997). 


\section{Conclusions}

In vitro anther culture is efficiently applied in research and breeding programs of wheat (Triticum aestivum L.) to realize homogeneity in a single generation. The technology contributes to a more accurate evaluation of QTL $\times$ environmental interactions and is applied in genetic research for marker-trait association study, genomics and as a target for transformation, genetic engineering, gene mapping, and mapping of quantitative trait loci (QTLs).

Most of the studies indicate that the genetic improvement (the crossing with responsive genotypes), application of convenient stress pre-treatments (heat, cold and chemical components) and improvement in the composition of anther culture media and culture conditions are more efficient in stimulating anther culture androgenesis in a wide range of wheat genotypes. Moreover, the application of anther culture method with the mentioned improvements contributes to overcoming the problem of genotype dependency and the occurrence of albinism in wheat (Triticum aestivum L.).

High rates of spontaneous doubled haploid lines could be obtained in wheat and cereal plants produced by anther culture. In addition, the use of colchicine and anti-mitotic chemicals at an early stage of anther culture or as root immersion treatment may contribute to the increase of genome doubling in wheat (Triticum aestivum L.).

\section{References}

Al-Ashkar, I.M. (2014). Genetic contribution of parental genotypes on anther culture response of bread wheat $\mathrm{F}_{1}$ hybrids. Middle East Journal of Agriculture Research, 3(3), 472-478. Google scholar

Ankele, E., Heberle-Bors, E., Pfosser, M.F., Hofinger, B.J. (2005). Searching for mechanisms leading to albino plant formation in cereals. Acta Physiologiae Plantarum, 27(4), 651-665. https:// doi.org/10.1007/s11738-005-0069-4

Bajer, A.S., Molè-Bajer, J. (1986). Drugs with colchicine-like effects that specifically disassemble plant but not animal microtubules. Annals of the New York. Academy of Sciences, 466, 767-784. DOI: 10.1111/j.17496632.1986.tb38458.x

Barnabás, B., Kovács, G. (1992). Application of in vitro techniques in cereal pollen biology. In: Ottaviano, E., Gorla, M.S., Mulcahy, D.L., Mulcahy, G.B. (Eds.), Angiosperm Pollen and Ovules (pp. 291-297). New York, NY: Springer. https://doi.org/10.1007/978-1-46122958-2_46

Barnabás, B., Pfahler, P.L., Kovács, G. (1991). Direct effect of colchicine on the microspore embryogenesis to produce dihaploid plants in wheat (Triticum aestivum L.). Theoretical and Applied Genetics, 81(5), 675678. https://doi.org/10.1007/BF00226736

Barnabás, B., Szakacs, E., Karsai, I., Bedő, Z. (2001). In vitro androgenesis of wheat: from fundamentals to practical application. Euphytica, 119 (1-2), 211-216. https://doi.org/10.1023/A:1017558825810

Barnabás, B., Szakács, É., Liszt, K. (1988). Cytological aspects of in vitro androgenesis in cereals. In: Cresti, M., Gori, P., Pacini, E. (Eds.), Sexual Reproduction in Higher Plants (pp. 113-118). Berlin, Heidelberg: Springer-Verlag. https://doi.org/10.1007/978-3-642-73271-3_18

Biesaga-Kościelniak, J. (2001). Zearalenone as a new hypothetical regulator of plant growth and development. In: Monograph of Institute of Plant Physiology (pp. 1-35). Kraków, Poland: Polish Academy of Sciences. Google Scholar

Blakeslee, A.F., Belling, J., Farnham, M.E., Bergner, A.D. (1922). A haploid mutant in the jimson weed, "Datura stramonium". Science, 55 (1433), 646-647. http://doi.org/10.1126/science.55.1433.646
Broughton, S. (2008). Ovary co-culture improves embryo and green plant production in anther culture of Australian spring wheat (Triticum aestivum L.). Plant Cell, Tissue and Organ Culture, 95, 185-195. https://doi.org/10.1007/s11240-008-9432-7

Broughton, S. (2011). The application of $n$-butanol improves embryo and green plant production in anther culture of Australian wheat (Triticum aestivum L.) genotypes. Crop and Pasture Science, 62(10), 813822. https://doi.org/10.1071/CP11204

Broughton, S., Castello, M., Liu, L., Killen, J., Hepworth, A., O’Leary, R. (2020). The effect of caffeine and trifluralin on chromosome doubling in wheat anther culture. Plants, 9(1), article 105. https:// doi.org/10.3390/plants9010105

Caredda, S., Doncoeur, C., Devauxp, Sangwanr, Clementc. (2000). Plastid differentiation during androgenesis in albino and non albino producing cultivars of barley (Hordeum vulgare L.). Sexual Plant Reproduction, 13, 95-104. https://doi.org/10.1007/s004970000043

Castillo, A.M., Cistué, L., Vallés, M.P., Soriano, M. (2009). Chromosome doubling in monocots. In: Touraev, A., Forster, B.P., Jain, S.M. (Eds.), Advances in Haploid Production in Higher Plants (pp. 329-338). Dordrecht, The Netherlands: Springer. https:// doi.org/10.1007/978-1-4020-8854-4_27

Castillo, A.M., Sánchez-Díaz, R.A., Vallés, M.P. (2015). Effect of ovary induction on bread wheat anther culture: ovary genotype and developmental stage, and candidate gene association. Frontiers in Plant Science, 6, article 402. https://doi.org/10.3389/fpls.2015.00402

Chaudhary, H.K., Badiyala, A., Jamwal, N.S. (2015). New frontiers in doubled haploidy breeding in wheat. Agricultural Research Journal, 52 (4), 1-12. https://doi.org/10.5958/2395-146X.2015.00053.8

Chaudhary, H.K., Dhaliwal, I., Singh, S., Sethi, G.S. (2003). Genetics of androgenesis in winter and spring wheat genotypes. Euphytica, 132, 311-319. https://doi.org/10.1023/A:1025094606482

Chen, J.F., Cui, L., Malik, A.A., Mbira, K.G. (2011). In vitro haploid and dihaploid production via unfertilized ovule culture. Plant Cell, Tissue and Organ Culture, 104, 311-319. https://doi.org/10.1007/s11240010-9874-6

Cistué, L., Romagosa, I., Batlle, F., Echàvarri, B. (2009). Improvements in the production of doubled haploids in durum wheat (Triticum turgidum L.) through isolated microspore culture. Plant Cell Reports, 28, 727-735. https://doi.org/10.1007/s00299-009-0690-6

Cistué, L., Soriano, M., Castillo, A.M., Vallés, M.P., Sanz, J.M., Echàvarri, B. (2006). Production of doubled haploids in durum wheat (Triticum turgidum L.) through isolated microspore culture. Plant Cell Reports, 25, 257-264. https://doi.org/10.1007/s00299-005-0047-8

Coelho, M.B., Scagliusi, S.M.M., Lima, M.I.P.M., Consoli, L., Grando, M.F. (2018). Androgenic response of wheat genotypes resistant to fusariosis. Pesquisa Agropecuaria Brasileira, 53, 575-582. https:// doi.org/10.1590/s0100-204x2018000500006

Daghma, D.E.S., Hensel, G., Rutten, T., Melzer, M., Kumlehn, J. (2014). Cellular dynamics during early barley pollen embryogenesis revealed by time-lapse imaging. Frontiers in Plant Science, 5, article 675. https:/ / doi.org/10.3389/ fpls.2014.00675

Dagüstü, N. (2008). Diallel analysis of anther culture response in wheat (Triticum aestivum L.). African Journal of Biotechnology, 7(19), 3419-3423. Google Scholar

Datta, S.K., Wenzel, G. (1987). Isolated microspore derived plant formation via embryogenesis in Triticum aestivum L., Plant Science, 48(1), 49-54. https://doi.org/10.1016/0168-9452(87)90069-0

Datta, S.K. (2005). Androgenic haploids: factors controlling development and its application in crop improvement. Current Science, 89(11), 1870 -1878. https://www.jstor.org/stable/24111119

Day, A., Ellis, T.N. (1985). Deleted forms of plastid DNA in albino plants from cereal anther culture. Current Genetics, 9(8), 671-678. https:// doi.org/10.1007/BF00449820

De Buyser, J., Henry, Y., Lonnet, P., Herzog, R., Hespel, A. (1987). Florin-a doubled haploid wheat variety developed by the anther culture method. Plant Breeding, 98, 53-56. https://doi.org/10.1111/j.14390523.1987.tb01089.x

Dhooghe, E., Van Laere, K., Eeckhaut, T., Leus, L., Van Huylenbroeck, J. (2011). Mitotic chromosome doubling of plant tissues in vitro. Plant Cell, Tissue and Organ Culture (PCTOC), 104(3), 359-373. https://doi.org/10.1007/s11240-010-9786-5 
Ding, X.L., Luckett, D.J., Darvey, N.L. (1991). Low-dose gammairradiation promotes wheat anther culture response. Australian Journal of Botany, 39(5), 467-474. https://doi.org/10.1071/BT9910467

Dunwell, J.M. (2010). Haploids in flowering plants: origins and exploitation. Plant Biotechnology Journal, 8, 377-424. https:// doi.org/10.1111/j.1467-7652.2009.00498.x

Dwivedi, S.L., Britt, A.B., Tripathi, L., Sharma, S., Upadhyaya, H.D., Ortiz, R. (2015). Haploids: constraints and opportunities in plant breeding. Biotechnology Advances, 33(6), 812-829. https:// doi.org/10.1016/j.biotechadv.2015.07.001

El-Hennawy, M.A., Abdalla, A.F., Shafey, S.A., Al-Ashkar, I.M. (2011). Production of doubled haploid wheat lines (Triticum aestivum L.) using anther culture technique. Annals of Agricultural Sciences, 56, 63-72. https://doi.org/10.1016/j.aoas.2011.05.008

Fehér, A. (2005). Why somatic plant cells start to form embryos? In: Mujib, A., Samaj, J. (Eds.), Somatic Embryogenesis (Plant Cell Monographs) (vol 2, pp. 85-101). Berlin/Heidelberg: Springer. https:// doi.org/10.1007/7089_019

González, M., Hernádez, I., Jouve, N. (2006). Analysis of anther culture response in hexaploid triticale. Plant Breeding, 116(3), 302-304. https:/ doi.org/10.1111/j.1439-0523.1997.tb01003.x

Gorbunova, V.Y., Kruglova, N.N., Abramov, S.N. (2001). The induction of androgenesis in vitro in spring soft wheat. Balance of exogenous and endogenous phytohormones. Biology Bulletin of the Russian Academy of Sciences, 28(1), 25-30. https://doi.org/10.1023/A:1026602603527

Graf, R.J., Hucl, P., Orshinsky, B.R., Kartha, K.K. (2003). “McKenzi” hard red spring wheat. Canadian Journal of Plant Science, 83, 565-569. https:// doi.org/10.4141/P02-115

Grauda, D., Mikselsone, A., L̇isina, N., Žagata, K., Ornicāns, R., Fokina, O., Lapiòa, L., Rashal, I. (2014). Anther culture effectiveness in producing doubled haploids of cereals. In: Proc. of the Latvian Academy of Sciences. Section B. Natural, Exact, and Applied Sciences, 142-147. https:// doi.org/10.2478/prolas-2014-0016

Grauda, D., Žagata, K., Lanka, G., Strazdina, V., Fetere, V., Lisina, N., Krasnevska, N., Fokina, O., Mikelsone, A., Ornicans, R., Belogrudova, I., Rashal, I. (2016). Genetic diversity of wheat (Triticum aestivum L.) plants-regenerants produced by anther culture. Genetics and Breeding, 20(4), 537-544. https://doi.org/10.18699/VJ16.176

Guha, S., Maheshwari, S.C. (1964). In vitro production of embryos from anthers of Datura. Nature, 204(4957), 497-497. https:// doi.org/10.1038/204497a0

Hansen, N.J.P., Andersen, S.B. (1996). In vitro chromosome doubling potential of colchicine, oryzalin, trifluralin and APM in Brassica napus microspore culture. Euphytica, 88, 159-164. https://doi.org/10.1007/ BF00032447

Hansen, N.J.P., Andersen, S.B. (1998a). In vitro chromosome doubling with colchicine during microspore culture in wheat (Triticum aestivum $\mathrm{L}$.) Euphytica, 102, 101-108. https://doi.org/10.1023/A:1018348816205

Hansen, N.J.P., Andersen, S.B. (1998b). Efficient production of doubled haploid wheat plants by in vitro treatment of microspores with trifluralin or APM. Plant Breeding, 117(5), 401-405. https:// doi.org/10.1111/j.1439-0523.1998.tb01963.x

Hao, M., Zhang, L., Luo, J., Yuan, Z., Yan, Z., Zhang, B. (2013). The genetic study utility of a hexaploid wheat $\mathrm{DH}$ population with nonrecombinant A- and B-genomes. Springerplus, 2, 131. https:// doi.org/10.1186/2193-1801-2-131

Hasan, M., Pauk, J., Kertesz, Z. (2014). In vitro androgenesis of some wheat (Triticum aestivum L.) varieties and their $\mathrm{F}_{1}, \mathrm{~F}_{2}$ progenies and combining ability of embryoid production. Progressive Agriculture, 18(2), 57-60. http://dx.doi.org/10.3329/pa.v18i2.18091

Hazarika, B.N. (2003). Acclimatization of tissue-cultured plants. Current Science, 85(12), 1704-1712. https://www.jstor.org/stable/24109975

He, D.G., Ouyang, J.W. (1984). Callus and plantlet formation from cultured wheat anthers at different developmental stages. Plant Science Letters, 33(1), 71-79. https://doi.org/10.1016/0304-4211(84)90070-1

Heberle-Bors, E. (1985). In vitro haploid formation from pollen: a critical review. Theoretical and Applied Genetics, 71(3), 361-374. https:// doi.org/10.1007/BF00251175

Holme, I.B., Olesen, A., Hansen, N.J.P., Andersen, S.B. (1999). Anther and isolated microspore culture response of wheat lines from northwestern and eastern Europe. Plant Breeding, 118, 111-117. https://doi.org/10.1046/j.1439-0523.1999.118002111.x
Hu, D.F., Yuan, Z.D., Tang, Y.L., Liu, J.P. (1986). "Jinghua No-1" a winter-wheat variety derived from pollen sporophyte. Science in China Series B-Chemistry, Biological, Agricultural, Medical and Earth Sciences, 29(7), 733-745. https://doi.org/10.1360/yb1986-29-7-733

Hu, T.C., Kasha, K.J. (1997). Improvement of isolated microspore culture of wheat Triticum aestivum L. through ovary co-culture. Plant Cell Reports, 16, 520-525. https://doi.org/10.1007/BF01142316

Hunter, C.P. (1987). Plant regeneration method. European patent, 1987. Application No. 872007737. IRRI (1995, 1998) International Rice Research Institute Program Report, IRRI, Los Banos, Philippines. Google Scholar

Inagaki, M.N. (2003). Doubled haploid production in wheat through wide hybridization. In: Malszynnski, M., Kasha, K.J., Forster, B.P., Szarejko, I., (Eds.), Doubled Haploid Production in Crop Plants: A manual (pp. 53-58). Dordrecht, The Netherlands: Kluwer Academic Publishers. https://doi.org/10.1007/978-94-017-1293-4_9

Indrianto, A., Barinova, I., Touraev, A., Heberle-Bors, E. (2001). Tracking individual wheat microspores in vitro: identification of embryogenic microspores and body axis formation in the embryo. Planta, 212, 163 -174. https://doi.org/10.1007/s004250000375

Islam, S.M.S. (2010). Effect of embryoids age, size and shape for improvement of regeneration efficiency from microspore-derived embryos in wheat (Triticum aestivum L.). Plant Omics, 3(5), 149-153. https://www.cabdirect.org/cabdirect/abstract/20103319291

Islam, S.M.S., Tuteja, N. (2012). Enhancement of androgenesis by abiotic stress and other pretreatments in major crop species. Plant Science, 182, 134-144. https://doi.org/10.1016/j.plantsci.2011.10.001

Jacquard, C., Nolin, F., Hécart, C., Grauda, D., Rashal, I., DhondtCordelier, S., Sangwan, R.S., Devaux, P., Mazeyrat-Gourbeyre, F., Clément, C. (2009). Microspore embryogenesis and programmed cell death in barley: Effects of copper on albinism in recalcitrant cultivars. Plant Cell Reports, 28(9), 1329-1339. https://doi.org/10.1007/s00299009-0733-z

Jensen, C.J. (1974). Chromosome doubling techniques in haploids. In: Kasha, K.J. (Ed.), Haploids in Higher Plants: Advances and Potential (pp. 153-190). Guelph, Canada: The University of Guelph. Google Scholar

Kanbar, O.Z., Lantos, C, Kiss, E., Pauk, J. (2020a). Androgenic responses of winter wheat (Triticum aestivum L.) combinations in in vitro anther culture. Genetika, 52(1), 337-350. https://doi.org/10.2298/ GENSR2001335K

Kanbar, O.Z., Lantos, C., Chege, P.K., Kiss E., Pauk, J. (2020b). Generation of doubled haploid lines from winter wheat (Triticum aestivum $\mathrm{L}$.) breeding material using in vitro anther culture. Czech Journal of Genetics and Plant Breeding, 56(4), 150-158. https:// doi.org/10.17221/113/2019-CJGPB

Kasha, K.J. (2005). Chromosome doubling and recovery of doubled haploid plants. In: Don Palmer, C., Keller, W.A., Kasha, K.J. (Eds.), Haploids in Crop Improvement II (vol 56, pp. 123-152). Berlin/ Heidelberg, Germany: Springer. https://doi.org/10.1007/3-54026889-8_7

Kasha, K.J., Hu, T.C., Oro, R., Simion, E., Shim, Y.S. (2001). Nuclear fusion leads to chromosome doubling during mannitol pre-treatment of barley (Hordeum vulgare L.) microspores. Journal of Experimental Botany, 52(359), 1227-1238. https://doi.org/10.1093/ jexbot/52.359.1227

Kasha, K.J., Maluszynski, M. (2003). Production of doubled haploids in crop plants. An introduction. In: Maluszynski, M., Kasha, Kj., Forster, Bp., Szarejko, I. (Eds.), Doubled Haploid Production in Crop Plants (pp. 1-4). Dordrecht: Springer. https://doi.org/10.1007/97894-017-1293-4_1

Khiabani, B.N, Vedadi, C, Rahmani, E, Shalmani, M.A.M. (2008). Response of some Iranian wheat genotypes to anther culture system. Indian Journal of Biotechnology, 7(4), 531-535. http://nopr.niscair.res.in/ handle/123456789/2361

Kim, K.M., Baenziger, P.S. (2005). A simple wheat haploid and doubled haploid production system using anther culture. In Vitro Cellular and Developmental Biology-Plant, 41, 22-27. https://doi.org/10.1079/ IVP2004594

Kondic-Spika, A., Vukosavljev, M., Kobiljski, B., Hristov, N. (2011). Relationships among androgenetic components in wheat and their 
responses to the environment. Journal of Biological Research, 16, 217-223. https://open.uns.ac.rs/handle/123456789/13744

Kondic-Spika, A.Đ., Kobiljski, B.Đ., Hristov, N.S. (2008). Efficiency of anther culture technique in the production of wheat double haploids. Matica Srpska for Natural Sciences, No 115, 35-40. https:// doi.org/10.2298/ZMSPN0815035K

Krzewska, M., Czyczyło-Mysza, I., Dubas, E., Gołębiowska-Pikania, G., Żur, I. (2015). Identification of QTLs associated with albino plant formation and some new facts concerning green versus albino ratio determinants in triticale $(\times$ Triticosecale Wittm.) anther culture. Euphytica, 206(1), 263-278. https://doi.org/10.1007/s10681-015-1509 $-\mathrm{x}$

Kush, G.S., Virmani, S.S. (1996). Haploids in plant breeding. In: Mohan Jain, S., Sopory, S.K., Veilleux, R.E. (Eds.), In vitro Production in Higher Plants (pp. 11-34). Dordrecht/Boston/London: Kluwer Academic Publishers.

Labbani, Z., De Buyser, J., Picard, E. (2007). Effect of mannitol pretreatment to improve green plant regeneration on isolated microspore culture in Triticum turyidum ssp. durum cv. 'Jennah Khetifa'. Plant Breeding, 126(6), 565-568. https://doi.org/10.1111/j.14390523.2007.01399.x

Lantos, C., Pauk, J. (2016). Anther culture as an effective tool in winter wheat (Triticum aestivum L.) breeding. Russian Journal of Genetics, 52, 794 -801. https://doi.org/10.1134/S102279541608007X

Lantos, C., Weyen, J., Orsini, J.M., Gnad, H., Schlieter, B., Lein, V. Kontoeski, S., Jacobi, A., Mihaly, R., Broughton, S., Pauk, J. (2013). Efficient application of in vitro anther culture for different European winter wheat (Triticum aestivum L.) breeding programmes. Plant Breeding 132(2), 149-154. https://doi.org/10.1111/pbr.12032

Lazaridou, T., Pankou, C., Xynias, I., Roupakias, D. (2016). Effect of D genome on wheat anther culture response after cold and mannitol pretreatment. Acta Biologica Cracoviensia Series Botanica, 58(1), 95-102. https://pubag.nal.usda.gov/catalog/5476800

Mahato, A., Chaudhary, H.K. (2019). Auxin induced haploid induction in wide crosses of durum wheat. Cereal Research Communications, 47, 552 565. https://doi.org/10.1556/0806.47.2019.31

Makowska, K., Oleszczuk, S. (2014). Albinism in barley androgenesis. Plant Cell Reports, 33(3), 385-392. https://doi.org/10.1007/s00299-0131543-x

Makowska, K., Oleszczuk, S., Zimny, A., Czaplicki, A., Zimny, J. (2015). Androgenic capability among genotypes of winter and spring barley. Plant Breeding, 134(6), 668-674. https://doi.org/10.1111/pbr.12312

Maluszynski, M., Kasha, K.J. Szarejko, I. (2003). Published double haploid protocols in plant species. In: Maluszynski, M., Kasha, K.J., Forster, B.P., Szarejko, I., (Eds), Haploid Production in Crop Plants: a Manual (pp. 309-335). Dordrecht, Netherlands: Kluwer Academic Publishers. https://doi.org/10.1007/978-94-017-1293-4_46

Marciniak, K., Kaczmarek, Z., Adamski, T., Surma, M. (2003). The antherculture response of triticale line $\times$ tester progenies. Cellular and Molecular Biology Letters, 8(2), 343-351. https:// pubmed.ncbi.nlm.nih.gov/12813569/

Masojc, P.O., Lukow, M., Mckenzie, R.I.H., Howes, N.K. (1993). Responsiveness to anther culture in cultivars and F1 crosses of spring wheat. Canadian Journal of Plant Science, 73, 777-783. https:// doi.org/10.4141/cjps93-100

Morejohn, L.C., Bureau, T.E., Molè-Bajer, J., Bajer, A.S., Fosket, D.E. (1987b). Oryzalin, a dinitroaniline herbicide, binds to plant tubulin and inhibits microtubule polymerization in vitro. Planta, 172, 252-264. https://doi.org/10.1007/BF00394595

Morejohn, L.C., Bureau, T.E., Tocchi, L.P., Fosket, D.E. (1984). Tubulins from different higher plant species are immunologically nonidentical and bind colchicine differentially. Proceedings of the National Academy Sciences of the United States of America, 81(5), 1440-1444. https:// doi.org/10.1073/pnas.81.5.1440

Morejohn, L.C., Bureau, T.E., Tocchi, L.P., Fosket, D.E. (1987a) Resistance of Rosa microtubule polymerization to colchicine results from a low-affinity interaction of colchicine and tubulin. Planta, 170(2), 230-241. https://doi.org/10.1007/BF00397893

Murovec, J., Bohanec, B. (2012). Haploids and doubled haploids in plant breeding, Plant Breeding, Dr. Ibrokhim Abdurakhmonov (Ed.), ISBN: 978-953-307-932-5. InTech, Available at: http:// www.intechopen.com/books/plant-breeding/haploids-and-doubledhaploids-in-plant-breeding.

Murthy, J.V., Kim, H.H., Hanesworth, V.R., Hugdahl, J.D., Morejohn, L.C. (1994). Competitive inhibition of high-affinity oryzalin binding to plant tubulin by the phosphoric amide herbicide AmiprophosMethyl. Plant Physiology, 105(1), 309-320. DOI: https:// doi.org/10.1104/pp.105.1.309

Navarro-Alvarez, W., Baenziger, P.S., Eskridge, K.M., Hugo, M., Gustafson, V.D. (1994). Addition of colchicine to wheat anther culture media to increase doubled haploid plant production. Plant Breeding, 112, 192-198. https://doi.org/10.1111/j.14390523.1994.tb00670.x

Niazian, M., Shariatpanahi, M.E. (2020). In vitro-based doubled haploid production: recent improvements. Euphytica, 216, article 69. https:// doi.org/10.1007/s10681-020-02609-7

Nitsch, J.P., Nitsch, C. (1969). Haploid plants from pollen grains. Science, 163(3862), 85-87. http://doi.org/10.1126/science.163.3862.85

Niu, Z., Jiang, A., Abu Hammad, W., Oladzadabbasabadi, A., Xu, S.S., Mergoum, M., Elias, E.M. (2014). Review of doubled haploid production in durum and common wheat through wheat $\times$ maize hybridization. Plant Breeding, 133, 313-320. https://doi.org/10.1111/ pbr.12162

Orlowska, R., Pachota, K.A., Machczinska, J., Niedziela, A., Makowska, K., Zimny, J., Bednarek, P.T. (2020). Improvement of anther cultures conditions using the Taguchi method in three cereal crops. Electronic Journal of Biotechnology, 43, 8-15. https://doi.org/10.1016/ j.ejbt.2019.11.001

Ouyang, J.W., Zhou, S.M., Jia, S.E. (1983). The response of anther culture to culture temperature in Triticum aestivum. Theoretical and Applied Genetics, 66(2), 101-109. https://doi.org/10.1007/ BF00265182

Pauk, J., Kertész, Z., Beke, B., Bóna, L., Csősz, M., Matuz, J. (1995). New winter wheat variety: "GK Délibáb" developed via combining conventional breeding and in vitro androgenesis. Cereal Research Communications, 23(3), 251-256. https://www.jstor.org/ stable/23783837

Pauk, J., Mihály, R., Puolimatka, M. (2003). Protocol of wheat (Triticum aestivum L.) anther culture. In: Maluszynski, M., Kasha, K.J., Forster, B.P., Szarejko, I. (Eds.), Doubled Haploid Production in Crop Plants, a manual (pp. 59-64). Dordrecht: Springer. https:// doi.org/10.1007/978-94-017-1293-4_10

Ponitka, A., Ślusarkiewicz-Jarzina, A. (2009). Regeneration of oat androgenic plants in relation to induction media and culture conditions of embryo-like structures. Acta Societatis Botanicorum Poloniae, 78(3), 209-213. https://doi.org/10.5586/asbp.2009.026

Pospisilova, J., Ticha, I., Kadleaeek, P., Haisel, D., Plzakova, S. (1999). Acclimatization of micropropagated plants to ex vitro conditions. Biologia Plantarum, 42(4), 481-497. https://doi.org/10.1023/ A:1002688208758

Przetakiewicz, A., Orczyk, W., Nadolska-Orczyk, A. (2003). The effect of auxin on plant regeneration of wheat, barley and triticale. Plant Cell, Tissue and Organ Culture, 73(3), 245-256. https://doi.org/10.1023/ A:1023030511800

Ravi, M., Chan, S.W. (2010). Haploid plants produced by centromeremediated genome elimination. Nature, 464, 615-618. https:// doi.org/10.1038/nature08842

Redha, A., Suleman, P. (2011). Effects of exogenous application of polyamines on wheat anther cultures. Plant Cell, Tissue and Oryan Culture, 105, 345-353. https://doi.org/10.1007/s11240-010-9873-7

Rizkalla, A.A., Al-Ansary, A.M.F., Attia, S.A.A., Haiba, A.A.A., Nasseef, J.E. (2012). Response of some Egyptian and introduced wheat hybrids to androgenic process. International Journal of Agricultural Research, 7(4), 205-214. DOI: 10.3923/ijar.2012.205.214

Rubtsova, M., Gnad, H., Melzer, M., Weyen, J., Gils, M. (2013). The auxins centrophenoxine and 2, 4D differ in their effects on non-directly induced chromosome doubling in anther culture of wheat (T. aestivum L.). Plant Biotechnology Reports, 7(3), 247-255. https://doi.org/10.1007/ s11816-012-0256-x

Sadasivaiah, R.S., Perkovic, S.M., Pearson, C., Postman, B., Beres, B.L. (2004). Registration of "AC Andrew" wheat. Crop Science, 44(2), 696697. https://doi.org/10.2135/cropsci2004.6960 
Sánchez-Díaz, R.A., Castillo, A.M. Vallés, M.P. (2013). Microspore embryogenesis in wheat: new marker genes for early, middle and late stages of embryo development. Plant Reproduction, 26, 287-296. https://doi.org/10.1007/s00497-013-0225-8

Seguí-Simarro, J.M., Nuez, F. (2008). Pathways to doubled haploidy: Chromosome doubling during androgenesis. Cytogenetic and Genome Research, 120(3-4), 358-369. https://doi.org/10.1159/000121085

Seldimirova, O.A., Kruglova, N.N., Titova, G.E., Batygina, T.B. (2017). Comparative ultrastructural analyses of the in vitro microspore embryoids and in vivo zygotic embryos of wheat as a basis for understanding of cytophysiological aspects of their development Russian Journal of Developmental Biology, 48, 185-197. https:// doi.org/10.1134/S1062360417030109

Seldimirova, O.A., Zaytsev, D.Y., Galin, I.R., Kruglova, N.N. (2016). Phytohormonal regulation of in vitro formation of wheat androgenic structures. Research Result Physiology (" Hayиный peзультат. Серия «Физиология»), 2(1 (7)), 3-8. https://www.elibrary.ru/item.asp? id $=25848824$

Sharma, S., Sethi, G.S., Chaudhary, H.K. (2005). Influence of winter and spring wheat genetic backgrounds on haploid induction parameters and trait correlations in the wheat $\times$ maize system. Euphytica, 144, 199-205. https://doi.org/10.1007/s10681-005-5812-9

Shi, Y.G., Lian, Y., Shi, H.W., Wang, S.G., Fan, H., Sun, D.Z., Jing, R.L. (2019). Dynamic analysis of QTLs for green leaf area duration and green leaf number of main stem in wheat. Cereal Research Communications, 47, 250-263. https://doi.org/10.1556/0806.47.2019.06

Shim, Y.S., Kasha, K.I., Simi, E., Letarte, J. (2006). The relationship between induction of embryogenesis and chromosome doubling in microspore cultures. Protoplasma, 228, 79-86. https:// doi.org/10.1007/s00709-006-0177-z

Soriano, M., Cistué, L., Castillo, A.M. (2008). Enhanced induction of microspore embryogenesis after $n$-butanol treatment in wheat (Triticum aestivum L.) anther culture. Plant Cell Reports, 27(5), 805-811. https://doi.org/10.1007/s00299-007-0500-y

Soriano, M., Cistué, L., Valle, M.P., Castillo, A.M. (2007). Effects of colchicine on anther and microspore culture of bread wheat (Triticum aestivum L.). Plant Cell, Tissue and Organ Culture, 91, 225-234. https:// doi.org/10.1007/s11240-007-9288-2

Sorrells, M.E., Gustafson, J.P., Somers, D., Chao, S., Benscher, D., Guedira-Brown, G., Huttner, E., Kilian, A., Mcguire, P.E., Ross, K., Tanaka, J., Wenzl, P., Williams, K., Qualset, C.O. (2011). Reconstruction of the synthetic W7984 $\times$ Opata M85 wheat reference population. Genome, 54, 1-8. https://doi.org/10.1139/g11054

Suenaga, K., Morshedi, A.R., Darvey, N.L. (1997). Haploid production of Australian wheat (Triticum aestivum L.) cultivars through wheat $\times$ maize (Zea mays L.) crosses. Australian Journal of Agricultural Research, 48, 1207-1212. https://doi.org/10.1071/A97007

Szechyńska-Hebda, M., Skrzypek, E., Dąbrowska, G., BiesagaKościelniak, J., Filek, M., Wędzony, M. (2007). The role of oxidative stress induced by growth regulators in the regeneration process of wheat. Acta Physiologiae Plantarum, 29(4), 327-337. https:// doi.org/10.1007/s11738-007-0042-5

Thomas, J., Chen, Q., Howes, N. (1997). Chromosome doubling of haploids of common wheat with caffeine. Genome, 40(4), 552-558. https://doi.org/10.1139/g97-072

Thomas, W.T.B., Forster, B.P., Gertsson, B. (2003). Doubled haploids in breeding. In: Maluszynski, M., Kasha, K.J., Forster, B.P., Szarejko, I. (Eds.), Doubled Haploid Production in Crop Plants, a manual (pp. 337350). Norwell: Kluwer Academic Publishers.

Torp, A.M., Hansen, A.L., Andersen, S.B. (2001). Chromosomal regions associated with green plant regeneration in wheat (Triticum aestivum L.) anther culture. Euphytica, 119(3), article 377. https:// doi.org/10.1023/A:1017554129904

Touraev, A., Pfosser, M., Heberle-Bors, E. (2001). The microspore: A haploid multipurpose cell. Advances in Botanical Research, 35, 53-109. https://doi.org/10.1016/S0065-2296(01)35004-8

Trejo-Tapia, G., Amaya, U.M., Morales, G.S., Sánchez, A.D.J., Bonfil, B.M., Rodríguez-Monroy, M., Jiménez-Aparicio, A. (2002). The effects of cold-pretreatment, auxins and carbon source on anther culture of rice. Plant Cell, Tissue and Organ Culture, 71(1), 41-46. https://doi.org/10.1023/A:1016558025840
Trigiano, R.N., Gray, D.J. (2016). Plant tissue culture, development, and biotechnology. CRC Press. p. 584.

Trottier, M.C., Collin, J., Comeau, A. (1993). Comparison of media for their aptitude in wheat anther culture. Plant Cell, Tissue and Organ Culture, 35, 59-67. https://doi.org/10.1007/BF00043940

Tuvesson, S., Ljungberg, A., Johansson, N., Karlsson, K.E., Suijs, L.W., Josset, J.P. (2000). Large-scale production of wheat and triticale double haploids through the use of a single-anther culture method. Plant Breeding, 119, 455-459. https://doi.org/10.1046/ j.1439-0523.2000.00536.x

Tuvesson, S.A., Von Post, R., Ljungberg, A. (2003). Wheat anther culture. In: Maluszynski, M., Kasha, K.J., Forster, B.P., Szarejko, I. (Eds.), Doubled Haploid Production in Crop Plants, a manual (pp. 71-76). Dordrecht/Boston/London: Kluwer Academic Publishers.

Vaughn, K.C., Debonte, L.R., Wilson, K.G., Schaffer, G.W. (1980). Organelle alteration as a mechanism for maternal inheritance. Science, 208(4440), 196-198. https://doi.org/10.1126/ science. 208.4440.196

Wędzony, M., Forster, B.P., Żur, I., Golemiec, E., Szechyńska-Hebda, M., Dubas, E., Gotębiowska, G. (2009). Progress in doubled haploid technology in higher plants. In: Touraev, A., Forster, B.P., Jain, S.M. (Eds.), Advances in Haploid Production in Higher Plants (pp. 1-33). Dordrecht: Springer. https://doi.org/10.1007/978-1-4020-8854-4_1

Weigt, D., Kiel, A., Nawracała, J., Pluta, M., Lacka, A. (2016). Solidstemmed spring wheat cultivars give better androgenic response than hollow-stemmed cultivars in anther culture. In Vitro Cellular and Developmental Biology-Plant, 52(6), 619-625. https://doi.org/10.1007/ s11627-016-9793-2

Weigt, D., Kiel, A., Siatkowski, I., Zyprych-Walczak, J., Tomkowiak, A., Kwiatek, M. (2020). Comparison of the androgenic response of spring and winter wheat (Triticum aestivum L.). Plants, 9(1), article 49. https:// doi.org/10.3390/plants 9010049

Weigt, D., Niemann, J., Siatkowski, I., Zyprych-Walczak, J., Olejnik, P., Kurasiak-Popowska, D. (2019). Effect of Zearalenone and Hormone Regulators on Microspore Embryogenesis in Anther Culture of Wheat. Plants, 8(11), article 487. https://doi.org/10.3390/ plants8110487

Yan, G., Liu, H., Wang, H., Lu, Z., Wang, Y., Mullan, D., Hamblin, J., Liu, C. (2017). Accelerated generation of selfed pure line plants for gene identification and crop breeding. Frontiers in Plant Science, 8, article 1786. https://doi.org/10.3389/fpls.2017.01786

Yasuhara, H. (2005). Caffeine inhibits callose deposition in the cell plate and the depolymerisation of microtubules in the central region of the phragmoplast. Plant and Cell Physiology, 46(7), 1083-1092. https:// doi.org/10.1093/pcp/pci121

Yildirim, M., Bahar, B., Genc, I., Hatipoglu, R., Altintas, S. (2008). Reciprocal effects in anther cultures of wheat hybrids. Biologia Plantarum, 52(4), 779-782. https://doi.org/10.1007/s10535-0080152-y

Zamani, I., Kovacs, G., Gouli-Vavdinoudi, E., Roupakias, D.G., Barnabas, B. (2000). Regeneration of fertile doubled haploid plants from colchicine-supplemented media in wheat anther culture. Plant Breeding, 119(6), 461-465. https://doi.org/10.1046/j.1439-0523.2000.00538.x

Zheng, M.Y., Konzak, C.F. (1999). Effect of 2, 4-dichlorophenoxyacetic acid on callus induction and plant regeneration in anther culture of wheat (Triticum aestivum L.). Plant Cell Reports, 19(1), 69-73. https:// doi.org/10.1007/s002990050712

Zhou, H., Konzak, C.F. (1997). Influence of genetic and environmental factors on anther culture response of wheat. Journal of Applied Genetics, 38(4), 393-406. Google Scholar

Ziauddin, A., Marsolais, A., Simion, E., Kasha, K.J. (1992). Improved plant regeneration from wheat anther and barley microspore culture using phenylacetic acid (PAA). Plant Cell Reports, 11(10), 489-498. https:// doi.org/10.1007/BF00236263

Ziegler, G., Dressler, K., Hess, D. (1990). Investigations on the anther culturability of four German spring wheat cultivars and the influence of light on regeneration of green vs. albino plants. Plant Breeding, 105, 40-46. https://doi.org/10.1111/j.1439-0523.1990.tb00450.x

Żur, I., Dubas, E., Krzewska, M., Janowiak, F. (2015). Current insights into hormonal regulation of microspore embryogenesis. Frontiers in Plant Science, 6, article 424. https://doi.org/10.3389/fpls.2015.00424 


\section{In vitro kultura antera kao efikasno primenjena tehnika za proizvodnju dvostrukih haploida pšenice (Triticum aestivum L.)}

\section{Osama Zuhair Kanbar · Csaba Lantos · Janos Pauk}

Sažetak: In vitro kultura antera je najčešće korištena tehnologija za proizvodnju dvostrukih haploida pšenice (Triticum aestivum L.) i drugih žitarica. Primena ove tehnologije omogućava dobijanje homozigotnih čistih linija iz heterozigotnog oplemenjivačkog materijala u jednoj generaciji. Ovaj rad pruža pregled najvažnijih faktora koji ograničavaju efikasnost kulture antera ozime pšenice (Triticum aestivum L.), poput genotipske zavisnosti i albinizma, pored drugih faktora koji uključuju vreme prikupljanja materijala za izolaciju, kao i uslove sredine u kojima su gajene donor biljke. Faktori koji poboljšavaju efikasnost kulture antera pšenice u smislu prevazilaženja genotipske zavisnosti i albinizma su takođe uvršteni u ovaj rad, poput genetičkog poboljšanja, primene odgovarajućih stresnih predtretmana, kao i poboljšanja sastava hranljivih podloga i uslova gajenja u kulturi. Pored toga navedeni su metodi udvostručavanja hromozoma za haploidnu pšenicu proizvedenu androgenezom, poput spontanog udvostručavanja broja hromozoma ili upotrebe kolhicina i anti-mitotičkih hemikalija u ranim fazama kulture antera ili tretmana potapanja korena.

Ključne reči: kultura antera, dvostruki haploidi, Triticum aestivum L., pšenica

This article is distributed under the terms of the Creative Commons Attribution 4.0 International License (http://creativecommons.org/licenses/by/4.0), which permits unrestricted use, distribution and reproduction in any medium, provided you give appropriate credit to the original author(s) and the source, provide a link to the Creative Commons license, and indicate if changes were made. 